\title{
IDE wt Allele
}

National Cancer Institute

\section{Source}

National Cancer Institute. IDE wt Allele. NCI Thesaurus. Code C112877.

Human IDE wild-type allele is located within 10q23-q25 and is approximately $122 \mathrm{~kb}$ in length. This allele, which encodes insulin-degrading enzyme protein, plays a role in the degradation of insulin and other bioactive peptides. 